\title{
The Disease Resistance Signaling Components EDS1 and PAD4 Are Essential Regulators of the Cell Death Pathway Controlled by LSD1 in Arabidopsis
}

\author{
Christine Rustérucci, ${ }^{a, 1}$ Daniel H. Aviv, ${ }^{\text {b,c,1 }}$ Ben F. Holt III, Jeffery L. Dangl,b,c,3 and Jane E. Parkera,2,3 \\ a Sainsbury Laboratory, John Innes Centre, Colney, Norwich NR4 7UH, United Kingdom \\ b Department of Biology, University of North Carolina, Chapel Hill, North Carolina 27599-3280 \\ c Curriculum in Genetics and Molecular Biology, University of North Carolina, Chapel Hill, North Carolina 27599-3280
}

\begin{abstract}
Specific recognition of pathogens is mediated by plant disease resistance $(R)$ genes and translated into a successful defense response. The extent of associated hypersensitive cell death varies from none to an area encompassing cells surrounding an infection site, depending on the $R$ gene activated. We constructed double mutants in Arabidopsis between positive regulators of $R$ function and a negative regulator of cell death, LSD1, to address whether genes required for normal $R$ function also regulate the runaway cell death observed in Isd1 mutants. We report here that EDS1 and $P A D 4$, two signaling genes that mediate some but not all $R$ responses, also are required for runaway cell death in the Isd1 mutant. Importantly, this novel function of EDS1 and PAD4 is operative when runaway cell death in Isd1 is initiated through an $R$ gene that does not require EDS1 or PAD4 for disease resistance. NDR1, another component of $R$ signaling, also contributes to the control of plant cell death. The roles of EDS1 and PAD4 in regulating Isd1 runaway cell death are related to the interpretation of reactive oxygen intermediate-derived signals at infection sites. We further demonstrate that the fate of superoxide at infection sites is different from that observed at the leading margins of runaway cell death lesions in Isd1 mutants.
\end{abstract}

\section{INTRODUCTION}

Plants have evolved mechanisms to detect and respond effectively to most pathogens. Analyses of genetic variation in plant responses to pathogens have identified corresponding gene pairs (resistance or $R$ genes in the plant and avirulence or avr genes in the pathogen) that mediate recognition and cause induction of plant resistance (Staskawicz et al., 1995). These local plant defenses are usually, although not invariably, associated with a form of programmed plant cell death known as the hypersensitive response (HR). The HR can lead to cell death surrounding the infection site (Holub et al., 1994). Localized necrosis also can induce a plant response called systemic acquired resistance, which heightens defenses in uninoculated tissues against a broad spectrum of pathogens (Yang et al., 1997; McDowell and Dangl, 2000).

One of the earliest biochemical changes associated with the $\mathrm{HR}$ is an oxidative burst producing reactive oxygen intermediates (ROI), including superoxide anion $\left(\mathrm{O}_{2}^{-}\right.$) as a proximal component, which can be dismutated rapidly to hydrogen peroxide $\left(\mathrm{H}_{2} \mathrm{O}_{2}\right)$ (Lamb and Dixon, 1997; Bolwell,

\footnotetext{
${ }^{1}$ These authors contributed equally to this work.

${ }^{2}$ Current address: Max-Planck Institute for Plant Breeding Research, Carl-von-Linne Weg 10, D-50829 Cologne, Germany.

${ }^{3}$ To whom correspondence should be addressed. E-mail parker@ mpiz-koeln.mpg.de; fax 49-221-5062353; or E-mail dang|@email. unc.edu.
}

1999; Grant and Loake, 2000). These may serve both as antimicrobial agents and as signaling molecules in local and systemic plant resistance. Nitric oxide (NO), a redox-active molecule with a critical role in the activation of mammalian defense responses (Schmidt and Walter, 1994), also functions as an important signal in plant resistance against pathogens (Delledonne et al., 1998; Durner et al., 1998). Salicylic acid (SA) accumulates in plant tissue responding to pathogen infection and is essential for the induction of systemic acquired resistance as well as being required for some $R$ gene-mediated responses, at least in Arabidopsis and tobacco (Gaffney et al., 1993; Delaney et al., 1994; Mur et al., 1997). Recent results suggest that the balance and cooperation between $\mathrm{NO}, \mathrm{ROI}$, and SA produced early in the plant resistance response is required for the full expression of the HR (Delledonne et al., 1998, 2001; Klessig et al., 2000). However, little is known about the sequence of events that determines local plant resistance. Also unclear is whether signals are transduced from an infection focus to first initiate, and then dampen, the HR.

Arabidopsis is the key genetic system with which to unravel disease resistance pathways (Glazebrook, 1999; Feys and Parker, 2000). Arabidopsis $R$ genes have been cloned that confer specific recognition of viral, bacterial, and oomycete pathogens (Parker et al., 2000). Their products 
belong to the most prevalent $\mathrm{R}$ protein class identified in a range of plant species that contains a central nucleotide binding (NB) domain and varying numbers of C-terminal leucine-rich repeats (LRRs) (Jones, 2000). NB-LRR proteins were further categorized into those with a coiled-coil (CC) motif at their $\mathrm{N}$ termini and those that have $\mathrm{N}$-terminal (TIR) similarity to the cytoplasmic domains of human and Drosophila Toll-like receptors (Jones, 2000).

Mutational analyses in Arabidopsis uncovered genes required as positive regulators of basal defense (Glazebrook, 1999; Feys and Parker, 2000). EDS1 is a necessary component of RPP1- and RPP4-specified resistance to the oomycete pathogen Peronospora parasitica $(P p)$ (Parker et al., 1996; Aarts et al., 1998) and is more generally required for resistance mediated by several tested Arabidopsis $R$ genes encoding TIR-NB-LRR proteins (Aarts et al., 1998). However, $E D S 1$ is not required for resistance conferred by any of the tested CC-NB-LRR $R$ genes (Aarts et al., 1998). Many, but not all, CC-NB-LRR $R$ genes examined are dependent on $N D R 1$, a gene identified through mutational analysis of RPM1mediated resistance to the bacterial pathogen Pseudomonas syringae expressing avrB (Century et al., 1995). Thus, EDS1 and NDR1 differentiate $R$ gene-mediated events that may, at least in several cases, be conditioned by particular $R$ protein structural types (for the current exceptions, see McDowell et al., 2000). Furthermore, ndr1 mutant plants retain an HR initiated by two $R$ genes, RPM1 and RPS5, even though they fail to prevent bacterial growth, suggesting that resistance and HR are separable (Century et al., 1995). EDS1 encodes a 72$\mathrm{kD}$ lipase-like protein that operates upstream of SA-mediated defenses (Falk et al., 1999), whereas NDR1 encodes a $25-\mathrm{kD}$ protein that has two putative membrane attachment domains (Century et al., 1997).

Mutational screens in Arabidopsis identified several other plant defense signaling genes that are components of SA signaling in the plant response against pathogens. For example, PAD4 (Glazebrook et al., 1997; Zhou et al., 1998) and SID1/EDS5 and SID2/EDS16 (Rogers and Ausubel, 1997; Nawrath and Métraux, 1999) function upstream of SA accumulation, whereas NPR1/NIM1 is an important regulator of responses downstream of SA (Cao et al., 1994; Delaney et al., 1995). Significantly, PAD4 encodes a lipase-like protein with catalytic motifs identical to EDS1 (Jirage et al., 1999). $E D S 1$ and $P A D 4$ operate upstream of pathogen-induced $S A$ accumulation, yet their expression can be enhanced by exogenous applications of SA. This finding reinforces evidence of an SA-associated positive feedback loop that may potentiate plant defense (Shirasu et al., 1997; Falk et al., 1999; Jirage et al., 1999). The pad4 mutation affects the same spectrum of $R$ gene functions detailed above for eds1, but the loss of resistance in pad4 is typically not as complete as in eds 1 (Glazebrook et al., 1997; Aarts et al., 1998; Feys et al., 2001).

Other Arabidopsis mutations deregulate disease resistance responses and/or HR-like plant cell death responses, suggesting that negative control of plant defense pathways also occurs (Morel and Dangl, 1997). Some of these display a "disease lesion mimic" phenotype that is a feature of several well-characterized crop plant mutants, in which necrotic lesions form spontaneously or can be induced by various biotic or abiotic stresses (Dangl et al., 1996; Büschges et al., 1997; Gray et al., 1997). Importantly, Arabidopsis plants carrying the recessive null Isd1 allele exhibit normal HR after infection by various incompatible pathogens, but runaway cell death $(R C D)$ is initiated subsequently at the margins of these sites (Dietrich et al., 1994). Spreading lesions in Isd1 can be induced by provision of $\mathrm{O}_{2}^{-} \cdot$ (Jabs et al., 1996) in uninfected tissues. This, together with observations that $\mathrm{O}_{2}{ }^{-} \cdot$ accumulation precedes lesion formation (Jabs et al., 1996), suggests that LSD1 responds to a superoxide-dependent signal(s) emanating from an infection site. SA possibly potentiates this pathway, because $I s d 1$ plants are acutely responsive to treatments with SA or chemically active SA analogs (Dietrich et al., 1994; Jabs et al., 1996). Thus, Isd1 lowers the threshold for both initiation and propagation of plant cell death beyond the HR. Isd1 plants also exhibit enhanced resistance to several normally virulent pathogens in a prelesioned state (Dietrich et al., 1994). We infer from these null phenotypes that LSD1 negatively regulates a signaling pathway(s) for basal defense and cell death and thereby may contribute to establishing a boundary to the plant HR (Dietrich et al., 1994). LSD1 encodes a zinc finger protein with homology with GATA-type transcription factors, and it has been suggested that the LSD1 protein functions either to negatively regulate a pro-death pathway component or to activate a repressor of plant cell death (Dietrich et al., 1997).

We constructed double mutant lines between the eds1, pad4, or ndr1 mutations and Isd 1 and assessed their effects on RCD and disease resistance phenotypes after pathogen infection, treatment with benzothiodiazole (BTH), a functional SA mimic (Görlach et al., 1996), or a superoxide generator. We demonstrate that $I s d 1$ does not affect the eds 1 , pad4, and ndr1 pathogen response phenotypes. However, both EDS1 and PAD4 are necessary for Isd1-conditioned RCD initiated by each tested stimulus. In contrast, NDR1 is required for $R C D$ in response to superoxide and partially reduces Isd1 RCD after pathogen inoculation or BTH treatment. The requirement for EDS1, PAD4, or NDR1 in Isd1 $R C D$ is separable from processes associated with the local $\mathrm{HR}$ and disease resistance; therefore, it is likely to operate at the level of defense signal potentiation in cells surrounding an infection site.

\section{RESULTS}

\section{EDS1 and PAD4 Are Required for Isd1 RCD Induced by BTH and Pathogens}

We first examined the responses of short-day-grown eds1/ Isd1, pad4//sd1, and ndr1//sd1c plants to a known inducer of 
RCD in Isd1, the SA mimic BTH (all mutants used were null alleles; see Methods). As shown in the top row of Figures $1 \mathrm{~A}$ and $1 \mathrm{~B}$, no phenotype was observed in leaves from either wild-type plants or plants with single mutations in eds1, pad4, or ndr1. Leaves from Isd1 or Isd1c plants, in contrast, formed the expected lesions in response to BTH 3 days after treat-

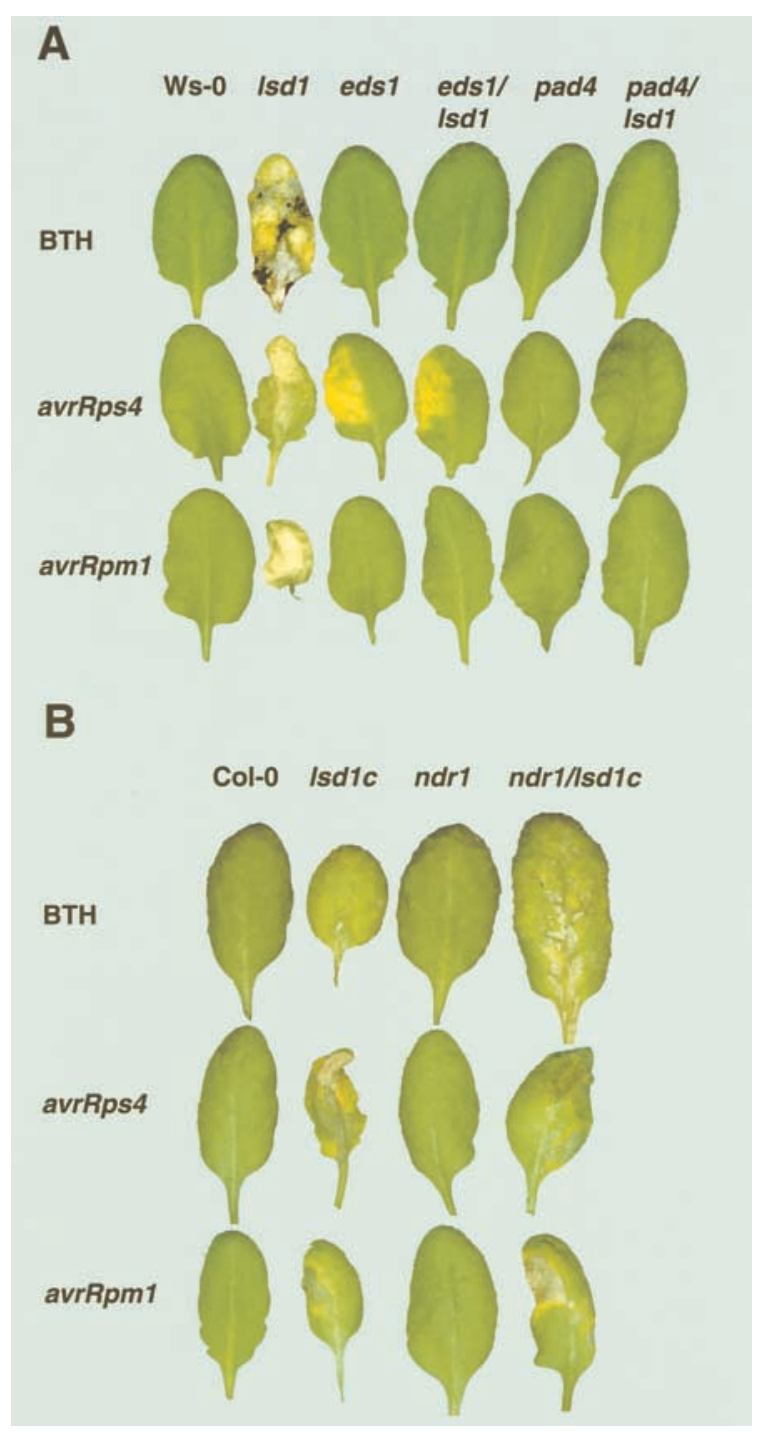

Figure 1. Lesion Phenotypes of Plant Lines after BTH Treatment or Bacterial Pathogen Inoculation.

Leaves of 4-week-old wild-type, single mutant, or double mutant plants were sprayed with $0.35 \mathrm{mM} \mathrm{BTH}$ or infiltrated on one side with low titer suspensions ( $10^{5}$ colony-forming units $/ \mathrm{mL}$ ) of $P$. syringae pv DC3000 expressing avrRps4 or avrRpm1. See Methods for further details. Leaves were photographed after 6 days of incubation, and each leaf is representative of 12 to 15 leaves. All treatments were repeated with similar results.

(A) Phenotypes of plant lines in accession Ws-0.

(B) Phenotypes of plant lines in accession Col-0. ment. We did not observe any lesions in leaves of plants with double mutations in eds1/lsd1 and pad4/Isd1, but lesions were observed in leaves of $n d r 1 / / s d 1 c$ plants. However, these lesions were not as extensive as those observed in leaves of Isd1 plants (Figure 1B). Thus, mutations in eds 1 or pad4 abolish BTH-induced RCD in Isd1 plants. Similar results were observed in these plants after treatment with another inducer of Isd1-mediated RCD, a shift in growing conditions from shortday to long-day conditions (data not shown).

We next assessed the interactions between these double mutant plants and normally avirulent strains of $P$. syringae pv tomato (DC3000) expressing either avrRpm1 or avrRps4. The different signaling requirements for RPM1 and RPS4 mentioned in the Introduction allowed us to measure the effects of the eds1, pad4, and ndr1 mutations on Isd1-induced phenotypes in the context of both an intact (resistant) and a defective (susceptible) local plant response by using isogenic $P$. syringae strains differing only in the avr gene they express. Plants were infiltrated with low doses of DC3000/avrRps4 to examine the genetic interactions between eds1 or pad4 in combination with Isd1. As expected, Wassilewskija (Ws-0) and Isd1 plants were resistant (Figure 2A). However, Ws-0 plants exhibited no visible phenotype, whereas Isd1 plants displayed lesions 3 to 4 days postinoculation (DPI) (Figure 1A). In contrast, eds 1 and eds $1 /$ /sd 1 double mutant plants were susceptible (Figure 2A). Additionally, eds1 and eds1/ Isd1 double mutant plants developed characteristic chlorotic disease symptoms, but no spreading lesions were observed in the eds $1 / / s d 1$ double mutant plants (Figure 1A). Plants with mutations in pad4 or both pad4 and Isd1 were intermediate; bacterial growth was $\sim 10$-fold less than in plants with mutations in eds 1 (Figure 2A). However, pad4/Isd1 plants did not exhibit chlorosis associated with disease or pathogeninduced lesioning associated with Isd1 RCD (Figure 1A). Thus, Isd1 does not influence the susceptibility of eds 1 or pad4 plants to DC3000/avrRps4.

We then challenged plants with low doses of DC3000/ avrRpm1. Wild-type, Isd1, eds1, and pad4 plants responded as expected (see Introduction); all genotypes were resistant, and RCD was visible in Isd1 leaves (Figures $1 \mathrm{~A}$ and 2C). eds1/Isd1 and pad4//sd1 double mutants also were resistant, but, surprisingly, they did not exhibit RCD. To confirm this observation, we infiltrated leaves with levels of DC3000/ avrRpm1 $\left(10^{7} / \mathrm{mL}\right)$ that induce an HR 6 to $8 \mathrm{hr}$ after inoculation (Grant et al., 1995). Plants from all genotypes (Ws-0, Isd1, eds1, eds1//sd1, pad4, and pad4//sd1) exhibited an HR. However, spreading lesions were observed in only Isd1 plants and not in eds1//sd1 or pad4/Isd1 (Table 1). Therefore, EDS1 and PAD4 are required for Isd1 RCD. Importantly, the requirement for EDS1 and PAD4 in RCD is independent of their signaling functions in RPS4-mediated disease resistance and separate from processes controlling RPM1 resistance.

We also infiltrated $n d r 1 / / s d 1 c$ double mutants with either DC3000/avrRps4 or DC3000/avrRpm1. Columbia (Col-0) and ndr1 plants were resistant to DC3000/avrRps4 (Figures 
A

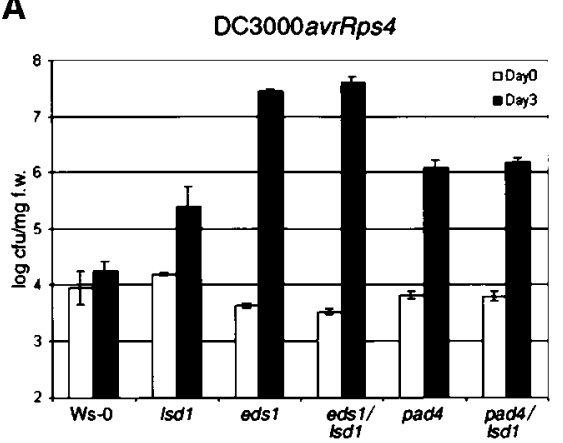

B

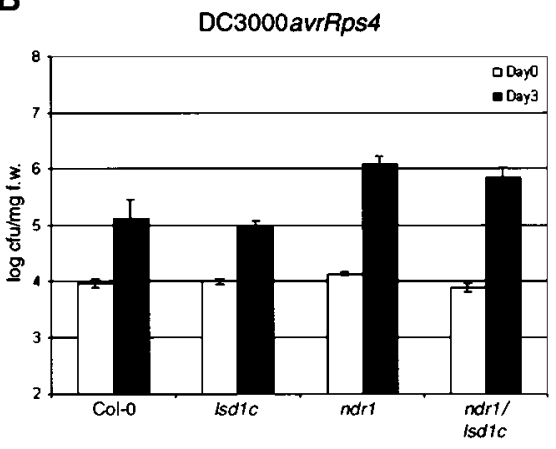

C

DC3000avrRpm1

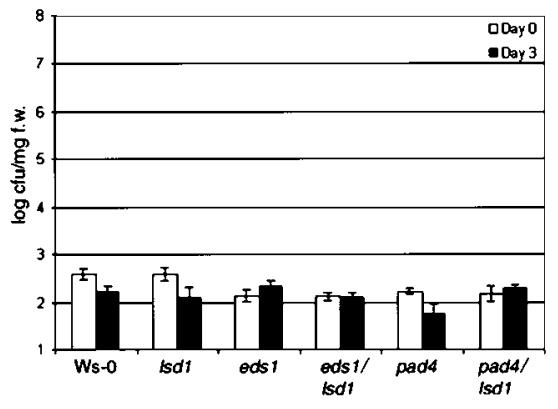

D

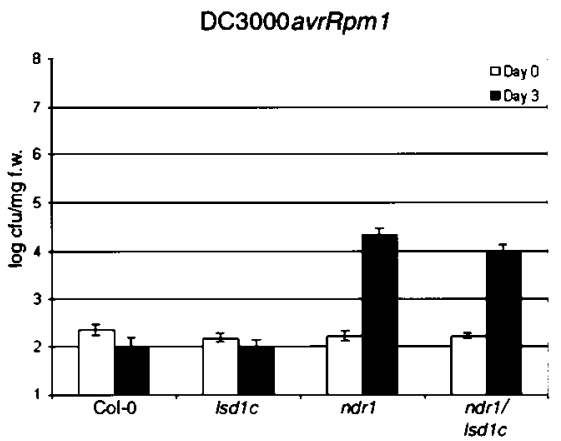

Figure 2. Bacterial Growth in Wild-Type, Single Mutant, and Double Mutant Plants.

Growth of $P$. syringae pv DC3000 expressing avrRps4 or avrRpm1 extracted from leaves at 0 (open bars) and 3 (closed bars) days after inoculation (initial titer, $10^{5}$ colony-forming units $/ \mathrm{mL}$ ). Data from Ws-0
1B and 2B), whereas $n d r 1$ plants were moderately susceptible to infection by DC3000/avrRpm1, consistent with previous analyses (Century et al., 1995) (Figures 1B and 2D). ndr1/Isd1c double mutants were resistant to DC3000/ avrRps4 and susceptible to DC3000/avrRpm1, as expected. However, we observed a partial suppression of RCD in these plants after inoculation with either bacterial strain (Figure 1B). Therefore, although ndr1 reduced Isd1 RCD, the level of reduction did not correlate with the loss of RPM1 function observed in ndr1 mutants.

We then examined the responses of the eds $1 / / s d 1$, pad4/ Isd1, and $n d r 1 / / s d 1 c$ mutant lines to normally avirulent isolates of the oomycete pathogen $P p$. This extends our analysis to an additional pathogen recognized by $R$ genes that differ in their signaling requirements, as outlined in the Introduction. As shown in Figures $3 \mathrm{~A}$ and $3 \mathrm{~B}, \mathrm{RPP} 1$-mediated resistance to Noco2 in cotyledons of Ws- 0 and Isd 1 is manifested as HR at points of attempted pathogen penetration 6 DPI. At this time, developing RCD is visible in Isd1 as an enlargement of the trypan blue-stained zone around an infection site (Figure $3 \mathrm{~A}$ ). In contrast, cotyledons of eds 1 and eds1//sd1 plants were susceptible to Noco2; we observed extensive mycelial growth as well as asexual sporulation (Figures 3A and 3B). Noco2 inoculation failed to elicit an HR in eds1/lsd1 plants. pad4 and pad4//sd1 plants were partially susceptible to Noco2; we observed trailing necrosis in response to Noco2 (Figure 3A), suggesting that HR was elicited but not sufficient to fully restrict pathogen growth. There was no RCD in either double mutant. Therefore, EDS1 and PAD4 are required for Isd1-mediated RCD, using $P p$ as an RCD inducer.

A similar analysis was performed by inoculating Emoy2 onto cotyledons of Col-0, Isd1c, ndr1, and ndr1/lsd1c plants. RPP4-mediated resistance to Emoy2 in Col-0 and Isd1c was associated with $\mathrm{HR}$ and the initiation of RCD in Isd1 cotyledons at 6 DPI (Figure 3A). ndr1 partially suppressed RPP4-mediated resistance to Emoy2; we observed an increased frequency of trailing necrosis (Figures $3 \mathrm{~A}$ and 3B). Isd1c plants expressed strong resistance to Emoy2, as shown by an increase in the proportion of HR sites, compared with Col-0 (Figure 3B). Surprisingly, ndr1//sd1c double mutants exhibited an intermediate phenotype (Figure $3 \mathrm{~B})$. Therefore, the loss of $L S D 1$ function enhanced host resistance to $P p$ early in the plant-pathogen interaction independent of NDR1 and presumably independent of the recognition conferred by $R P P 4$.

accession lines are presented in (A) and (C), and data from Col-0 accession lines are presented in (B) and (D). Bars represent the mean and \pm SD of four independent data points. Similar results were obtained in two independent experiments. cfu, colony-forming units; f.w., fresh weight. 
Table 1. Response Phenotypes of Wild-Type, Single Mutant, and Double-Mutant Lines to Inoculation with Avirulent Bacteria or Treatment with RB

\begin{tabular}{|c|c|c|c|c|c|c|c|}
\hline \multirow{2}{*}{$\begin{array}{l}\text { Arabidopsis } \\
\text { Lines }\end{array}$} & \multicolumn{3}{|c|}{ DC3000/avrRps4 } & \multicolumn{3}{|c|}{ DC3000/avrRpm1 } & \multirow{2}{*}{$\frac{\mathrm{RB}}{\mathrm{RCD}}$} \\
\hline & HR & $\mathrm{ROI}$ & RCD & HR & $\mathrm{ROI}$ & RCD & \\
\hline Ws-0 & + & + & - & + & ++ & - & - \\
\hline eds1 & - & - & - & + & ++ & - & - \\
\hline pad4 & + & + & - & + & ++ & - & - \\
\hline Isd1 & + & ++ & + & + & +++ & + & + \\
\hline eds $1 / / s d 1$ & - & - & - & + & +++ & - & - \\
\hline pad4//sd1 & + & + & - & + & ++ & - & - \\
\hline Col-0 & $(+)$ & $(+)$ & - & + & + & - & - \\
\hline$n d r 1$ & - & - & - & * & ++ & - & - \\
\hline Isd1c & $(+)$ & + & + & + & ++ & + & + \\
\hline$n d r 1 / / s d 1 c$ & - & - & $(+)$ & * & ++ & $(+)$ & - \\
\hline
\end{tabular}

Leaves were dipped in suspensions ( $10^{7}$ colony-forming units $/ \mathrm{mL}$ ) of $P$. syringae pv DC3000 expressing avrRps 4 or avrRpm1 or treated with a $2-\mu \mathrm{L}$ droplet of $20 \mathrm{mM}$ RB. Development of the plant HR and accumulation of ROI were scored 24 and $48 \mathrm{hr}$, and RCD was scored 4 days, after bacterial inoculation. The scores $(+),+,++$, and +++ reflect the intensity of staining with lactophenol-trypan blue for the HR and DAB for ROI. They are representative of at least six leaves per treatment. Asterisks denote an expanded, diffuse HR observed in $n d r 1$ and $n d r 1 / / s d 1 c$ plants. Pathogen inoculations were repeated twice with similar results. Leaves were scored for RCD 5 days after rose bengal application. Similar results were obtained in four independent experiments using 10 leaves per plant line.

We next examined the responses of leaves from mature (3- to 4-week-old) plants to inoculations of $P p$. This analysis allowed us to relate events associated with the plant HR to the initiation and spread of $/ s d 1$-conditioned RCD. As shown in Figures $4 \mathrm{~A}$ and $4 \mathrm{~B}$, discrete necrotic flecks formed on leaves of Ws- 0 or Col-0 in the area of incompatible $P p$ inoculation. Leaves of $I s d 1$ produced lesions that spread from the site of the localized resistance response (Figures $4 \mathrm{~A}$ and $4 \mathrm{~B})$. In contrast, asexual sporulation of $P p$ was observed on infected eds 1 and eds1/Isd1 leaves at 6 DPI, and no necrosis was observed. Leaves of pad4 and pad4/lsd1 plants supported some pathogen growth that was accompanied by trailing necrosis (Figure 4A). These results mirror those observed on cotyledons and further support the requirement for EDS1 and PAD4 for Isd1-mediated RCD. Leaves of $n d r 1$ and Col-0 responded in a similar manner to inoculation of $P p$ Emoy2, although the area of plant tissue undergoing an $\mathrm{HR}$ was marginally larger in $n d r 1$ than in Col-0 (Figure 4B; see also Figure 4D). The RCD was severely reduced in ndr1/ Isd1c compared with that in Isd1c (Figure 4B). Interestingly, the rate of initial lesion formation at the boundary of the HR was similar in Isd1c and ndr1/lsd1c (data not shown). However, by 3 to $4 \mathrm{DPI}$, lesions in $n d r 1 / / s d 1 c$ ceased to expand, whereas in $I s d 1 c$ they progressed and consumed the entire leaf by $\sim 6$ DPI (Figures $4 B$ and $4 D$ ).

\section{EDS1 and PAD4 Function in RCD Is Downstream of, or Independent from, the Local HR and Associated ROI Accumulation}

An oxidative burst giving rise to local $\mathrm{ROI}$ accumulation is an early event associated with the plant HR (Bestwick et al., 1997; Shirasu et al., 1997; Thordal-Christensen et al., 1997). Also, $\mathrm{O}_{2}{ }^{-} \cdot$ is necessary and sufficient for Isd1 RCD (Jabs et al., 1996). We examined the production of ROI in wild-type and mutant plants at the point of pathogen penetration to determine whether the effects of eds1, pad4, or ndr1 on Isd1-induced lesion propagation could be related to deficiencies in early ROI accumulation during the HR. Excised leaves were dipped in a solution of 3,3-diaminobenzidine (DAB) to visualize $\mathrm{H}_{2} \mathrm{O}_{2}$ and then inoculated with a $10-\mu \mathrm{L}$ droplet of avirulent $P p$ conidia, or they were dipped into suspensions of $P$. syringae. DAB polymerizes as a brown precipitate on contact with $\mathrm{H}_{2} \mathrm{O}_{2}$ in the presence of peroxidase (Shirasu et al., 1997; Thordal-Christensen et al., 1997), thus providing a useful marker for total peroxide accumulation.

The results from this analysis are shown in Figures $4 \mathrm{C}$ and 4D and are summarized in Table 1. A plant oxidative burst producing detectable local concentrations of $\mathrm{H}_{2} \mathrm{O}_{2}$ was observed only in plant genotypes undergoing an HR. Thus, eds1 (and eds1//sd1) plants challenged with Pp Noco2 or DC3000/avrRps4, in which resistance is suppressed, failed to elicit an oxidative burst or an HR. pad4 (and pad4/Isd1) plants generated high levels of $\mathrm{H}_{2} \mathrm{O}_{2}$ and also developed either trailing necrosis or an $\mathrm{HR}$, depending on the pathogen challenge. We conclude that EDS1 activity is required for the oxidative burst in EDS1-dependent $R$ gene-mediated responses, whereas $P A D 4$ functions either downstream or independently of ROI accumulation in the same responses. Both eds 1 and pad4 plants produced a wild-type RPM1mediated oxidative burst and $\mathrm{HR}$ after challenge with DC3000/avrRpm1 (Table 1). Thus, neither EDS1 nor PAD4 is required for the $\mathrm{HR}$-associated oxidative burst in this EDS1independent pathway. Yet, both are required for RCD in any of the tested contexts. Significantly, therefore, the requirements for EDS1 and PAD4 during Isd1-dependent RCD are unrelated to their effects on local $R$ gene-mediated HR. We conclude from these results that EDS1 and PAD4 provide necessary signaling functions leading to Isd $1 \mathrm{RCD}$ that are either downstream or independent of the local HR and associated ROI accumulation.

Interestingly, $n d r 1$ exhibited a reduction in the intensity of HR-associated DAB staining compared with that of Col-0 in response to $P p$ Emoy2, even though more host cells died, as measured by trypan blue (Figure 4D). This is in contrast to the enhanced $\mathrm{H}_{2} \mathrm{O}_{2}$ accumulation in Isd1 and Isd1c (Figures $4 \mathrm{C}$ and $4 \mathrm{D}$ ). The response of $n d r 1 / / s d 1 c$ plants was intermediate between that of $n d r 1$ and Isd1c alone, and the RCD boundary was less well defined than it was in wild-type plants (Figure 4D). These data suggest that the reduced ROI production in $n d r 1$ may be responsible for the attenuated RCD observed in the $n d r 1 / / s d 1 c$ double mutant. 
A
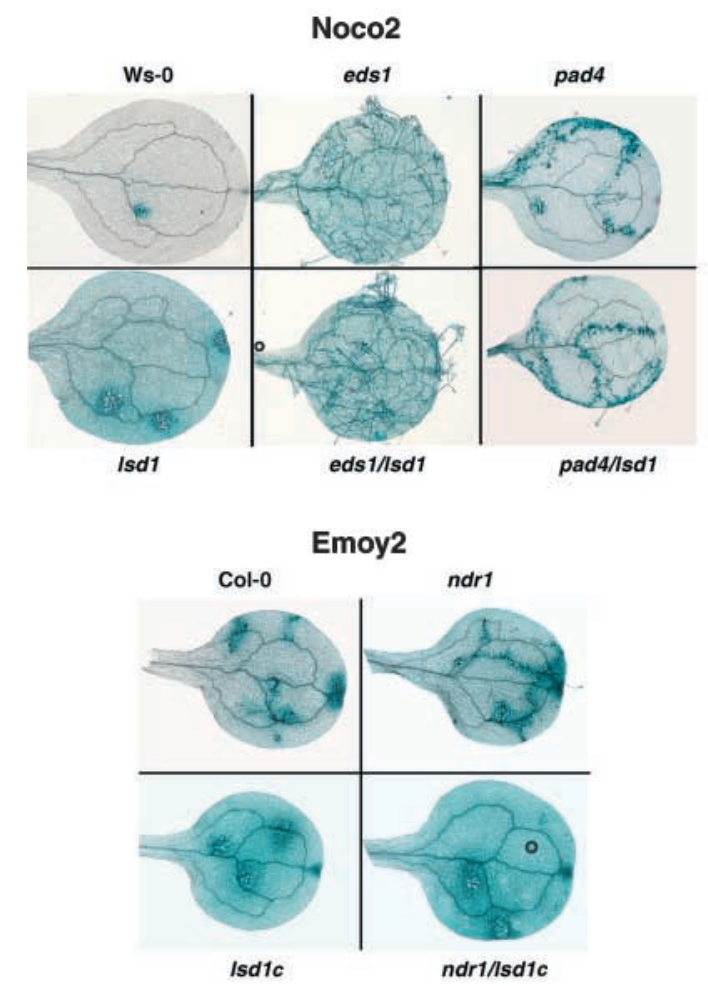

B
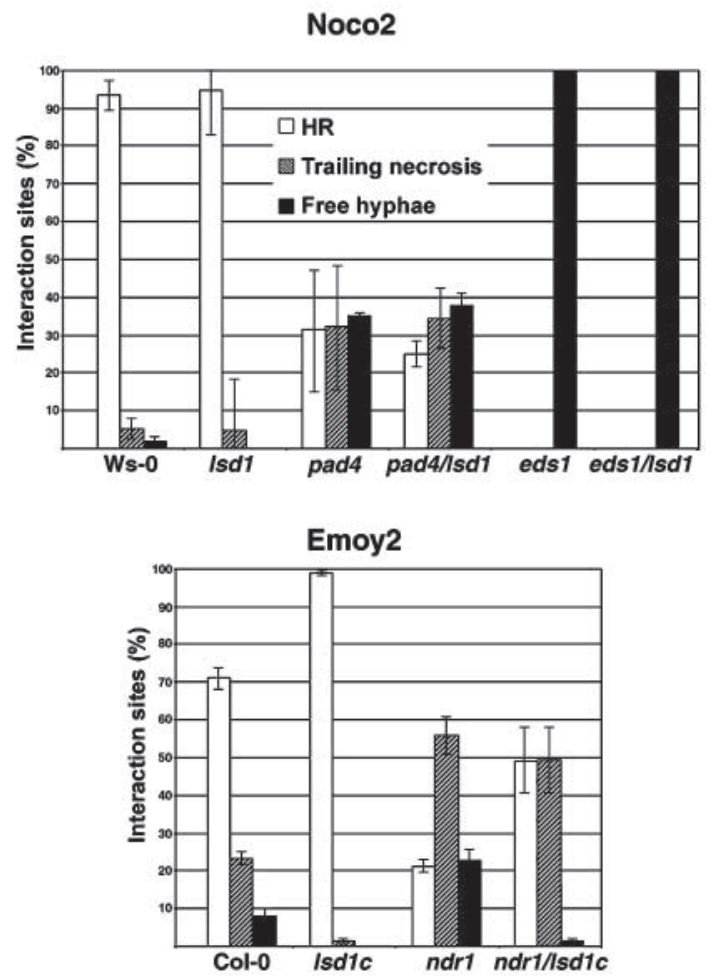

Figure 3. Infection Phenotypes of Plant Cotyledons Inoculated with Pp Isolates Noco2 and Emoy2.

(A) Cotyledons of 10-day-old seedlings were inoculated with Noco2 or Emoy2 $\left(5 \times 10^{4} \mathrm{spores} / \mathrm{mL}\right)$ and stained with lactophenol-trypan blue at 6 DPI to reveal $P p$ mycelium and dead plant cells.

(B) Trypan blue-stained cotyledons were harvested at $6 \mathrm{DPI}$, and individual plant-pathogen interaction sites were categorized as HR, trailing necrosis, or free mycelium. The percentage of each interaction type was scored from 40 to 80 cotyledons per experiment. Graphs represent the mean and \pm SE from three independent experiments.

\section{Fate of Superoxide at HR Margins and RCD Sites Is Different}

Because provision of $\mathrm{O}_{2}^{-} \cdot$ is both necessary and sufficient to induce RCD in Isd1 plants (Jabs et al., 1996), we addressed directly whether EDS1, PAD4, and NDR1 act as signaling intermediates between superoxide and the LSD1controlled cell death pathway. We elicited superoxide production by applying a discrete spot of rose bengal (RB) to leaves. In the presence of light, RB generates singlet oxygen that reduces to superoxide, which is rapidly dismutated to the more stable $\mathrm{H}_{2} \mathrm{O}_{2}$ (Knox and Dodge, 1984; Baker and Orlandi, 1995). RB-induced plant cell death was confined to the application site in wild-type Ws-0 leaves, but it induced $\mathrm{RCD}$ in Isd1 leaves, as shown in trypan blue-stained leaves at $3 \mathrm{DPI}$ (Figure $5 \mathrm{~A}$ ). We assessed $\mathrm{H}_{2} \mathrm{O}_{2}$ accumulation over a time course ( 3 to $48 \mathrm{hr}$ ) of RB treatment. Within $3 \mathrm{hr}$, we observed intense $D A B$ and trypan blue staining in the area of RB application (Figure 5A). From $27 \mathrm{hr}$ onward, cell death foci were fixed in Ws-0 but expanded in Isd1 (Figure 5A). In several independent experiments, RB treatments of wildtype, eds1//sd1, pad4/lsd1, and ndr1//sd1 plants failed to elicit RCD (Table 1). The same responses were observed in leaves of all genotypes infiltrated with a xanthine/xanthine oxidase superoxide-generating system that was previously shown to induce lesions in Isd1 (Jabs et al., 1996; data not shown).

In the earlier analysis by Jabs et al. (1996), superoxide accumulation was observed in live plant cells bordering the RCD lesions of Isd 1 leaves. We expected to see DAB precipitation at the leading margins of Isd1 lesions that would be generated upon dismutation of $\mathrm{O}_{2}^{-} \cdot$ to $\mathrm{H}_{2} \mathrm{O}_{2}$. However, there was no detectable $\mathrm{H}_{2} \mathrm{O}_{2}$ accumulation associated with Isd1 RCD lesions after either RB-induced cell death (Figure $5 \mathrm{~A}$ ) or $\mathrm{Pp}$ inoculation (Figure $5 \mathrm{~B}$ ). Superoxide production, measured by nitroblue tetrazolium (NBT) staining, was not detected at any point associated with the $P p$-induced HR or RB-induced cell death (data not shown). Superoxide accu- 
mulation, however, was observed at the boundaries of developing lesions in Isd1, confirming previous results (Jabs et al., 1996; data not shown). These results suggest that the fate of superoxide generated as a component of the $R$ gene-dependent HR is different from that produced in association with RCD in Isd1.

\section{DISCUSSION}

We demonstrate that $E D S 1$ and $P A D 4$, two positive regulators of plant disease resistance, are essential components of a cell death control pathway regulated by $L S D 1$ in re- sponse to pathogen infection, BTH application, or provision of superoxide. Most importantly, the requirement for EDS1 and PAD4 during Isd1 RCD is independent of their roles as mediators of various $R$ gene functions. Additionally, NDR1, a third disease resistance signaling component, contributes to Isd1 RCD during these responses.

\section{EDS1 and PAD4 Potentiate Plant Defense Signaling}

Our most important conclusion is that the requirements for EDS1 and PAD4 in Isd1 lesion formation are separable from their roles in localized $R$ gene-mediated plant cell death, as shown in the model in Figure 6. For example, neither EDS1

A
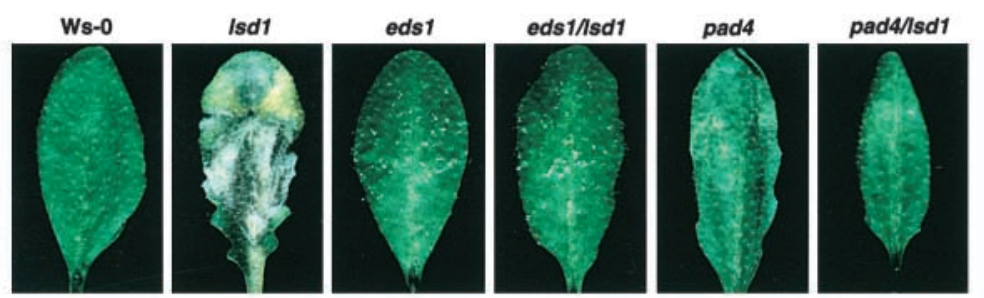

B
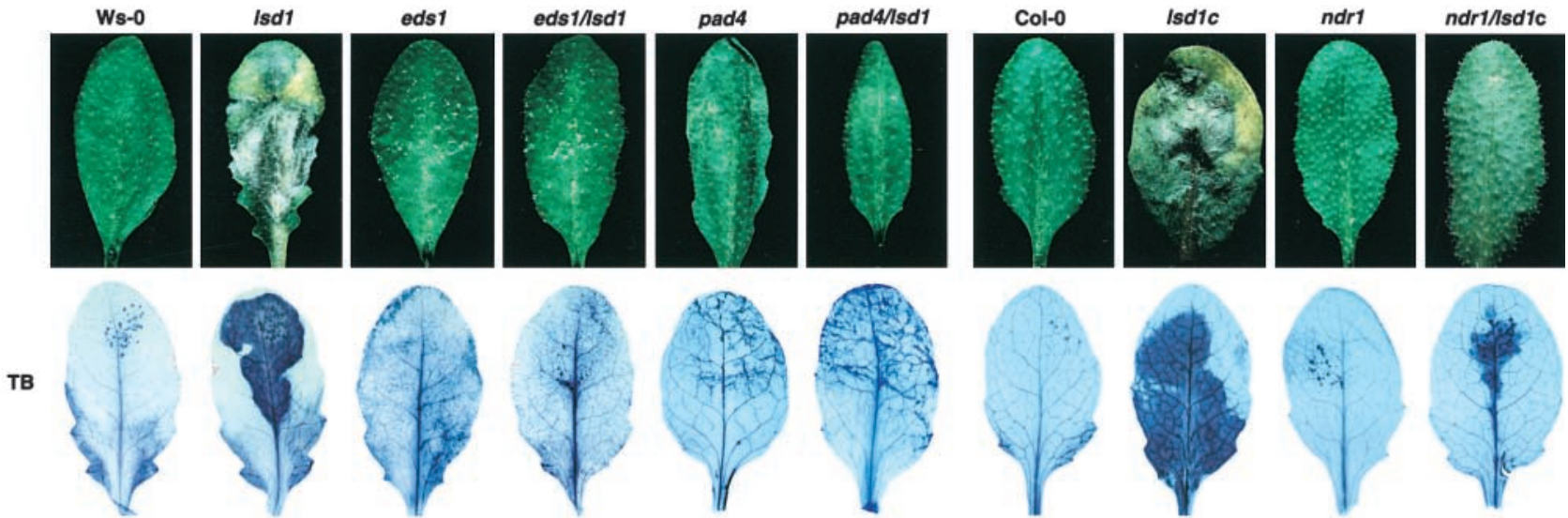

C
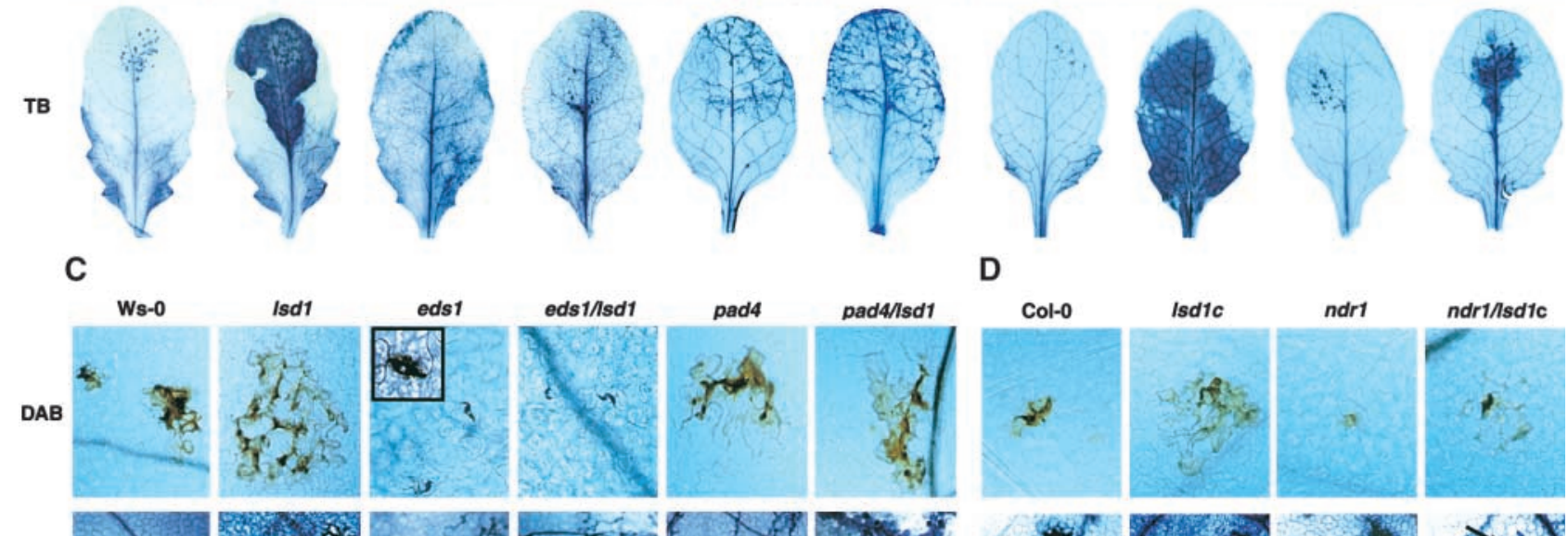

D

TB
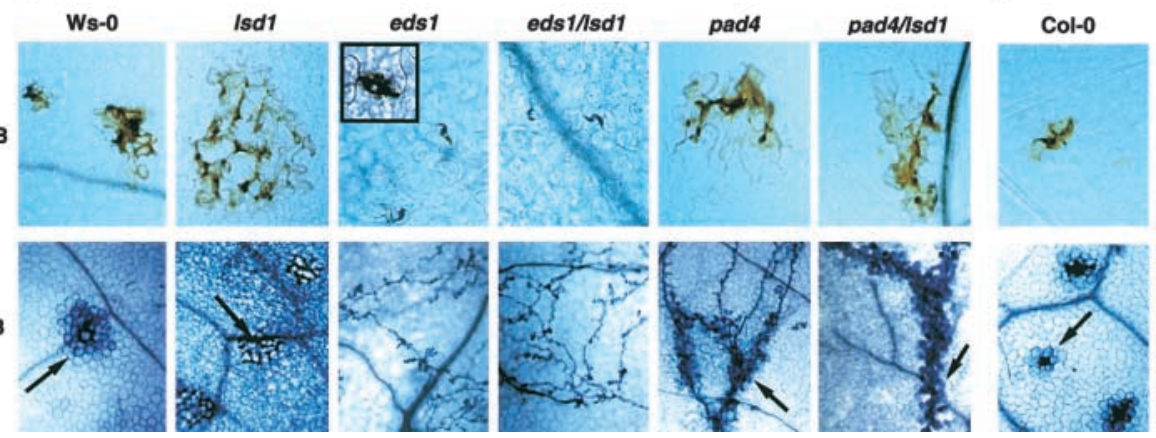

Isd1c

ndr1

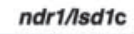

Figure 4. Disease Resistance and Runaway Plant Cell Death Phenotypes in Adult Leaves after Pp Inoculation.

Leaves of 4-week-old plants from wild-type, single mutant, and double mutant Ws-0 ([A] and [C]) and Col-0 ([B] and [D]) lines were inoculated by placing a 10- $\mu \mathrm{L}$ droplet of $P p$ spores on the top half of each leaf. Pp isolates Noco2 and Emoy2 (or Emwa1) were used for Ws-0 ([A] and [C]) and Col-0 ([B] and [D]) accession lines, respectively. Macroscopic phenotypes and corresponding trypan blue (TB) staining of plant-pathogen interaction sites are shown for whole leaves ([A] and [B]) and at $\times 200$ magnification ([C] and [D], bottom row) at 6 DPI. Hypersensitive plant cell death in trypan blue-stained leaves is marked with black arrows. Accumulation of $\mathrm{H}_{2} \mathrm{O}_{2}$ at interaction sites 32 hr after inoculation of leaves in the dark was measured using DAB and is shown at $\times 200$ magnification ([C] and [D], top row). The inset in the upper left corner of the eds 1 image at (C) shows an enlarged view of DAB staining restricted to the pathogen penetration site. Images are representative of four independent experiments using at least five leaves per genotype per experiment. 
A

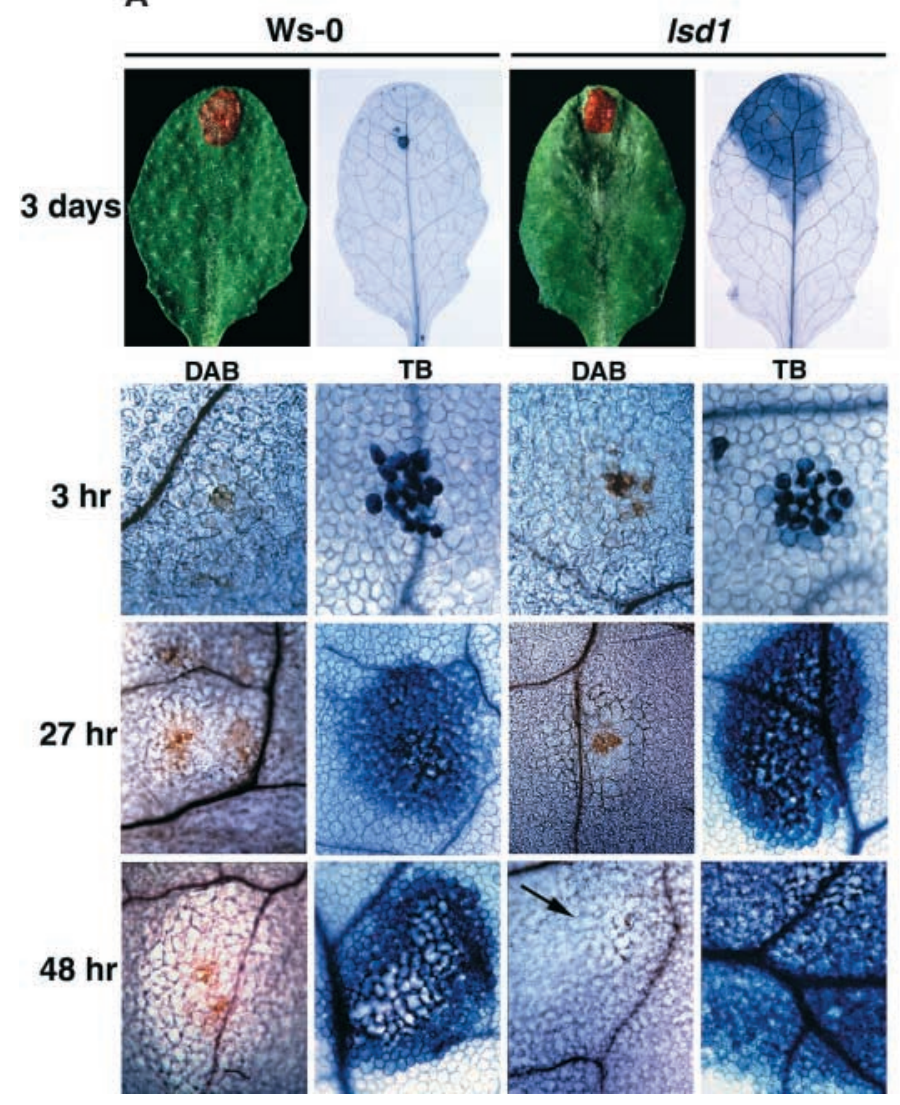

B
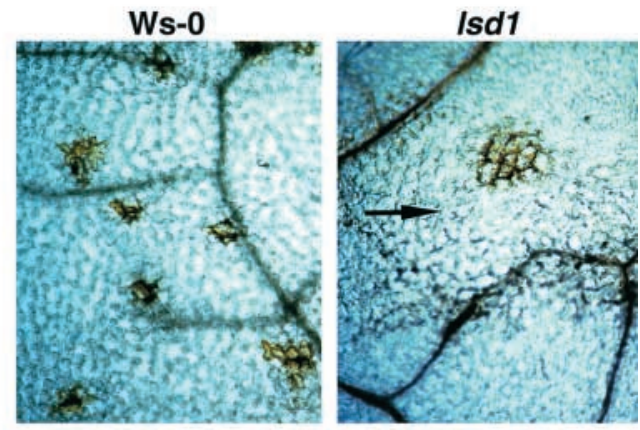

Col-0

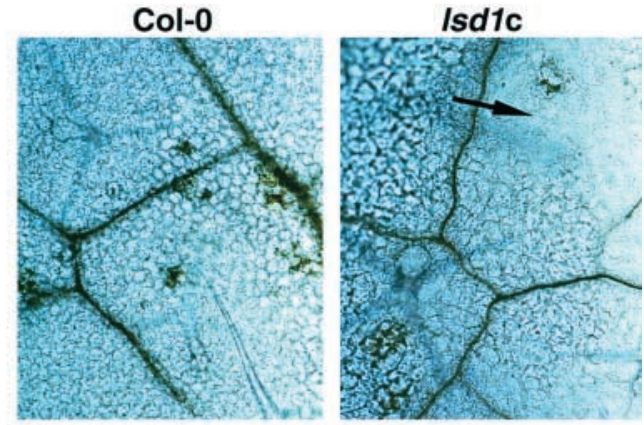

Figure 5. Localized $\mathrm{H}_{2} \mathrm{O}_{2}$ Accumulation in Wild-Type and /sd1 Leaves after RB Application or Pp Infection.

(A) A single 5- $\mu \mathrm{L}$ spot of $20 \mathrm{mM} \mathrm{RB}$ was applied to leaves of 4-week-old plants. $\mathrm{H}_{2} \mathrm{O}_{2}$ accumulation was measured over 7 days by staining with DAB. Leaves also were stained with lactophenol-trypan blue (TB) to measure the extent of plant cell death. Localized RB application gives rise to local $\mathrm{H}_{2} \mathrm{O}_{2}$ accumulation associated with a discrete patch of dead plant cells. In Ws-0, expansion of plant cell necrosis ceases by $27 \mathrm{hr}$, whereas in $/ s d 1$, the lesions expand. DAB-staining material is detected in the area of RB application but is not associated with the spreading $\mathrm{RCD}$ in $/ s d 1$ (black arrows).

(B) Leaves of 4-week-old plants were inoculated with a 10- $\mu \mathrm{L}$ droplet of $5 \times 10^{4}$ spores/mL Noco2 (Ws-0 and /sd1) or Emoy2 (Col-0 and /sd1c). Leaves were photographed 5 days after treatment. $\mathrm{H}_{2} \mathrm{O}_{2}$ accumulation, measured by DAB staining, was detected at plant-pathogen interaction sites but was not associated with spreading lesions, seen here as clear, unstructured cells (black arrows). Images are representative of three independent experiments using eight leaves per genotype per time point.

nor $P A D 4$ function in RPM1 resistance, yet both are required for RCD after RPM1 stimulation in Isd1. EDS1, but not $P A D 4$, is necessary for ROI production and $\mathrm{HR}$ after local RPS4- or RPP1-mediated pathogen recognition, yet both EDS1 and PAD4 are required for Isd1 RCD in these responses. We suggest that the activities of EDS1 and PAD4 leading to lesion formation in Isd1 are in defense signal potentiation, downstream or independent of the HR (Figure 6). The finding that eds 1 and pad4 suppress Isd1 RCD in response to applications of BTH, a functional mimic of the plant resistance signaling molecule $\mathrm{SA}$, is consistent with this idea. Other studies have shown the involvement of SA in signal potentiation during local and systemic plant de- fenses (Shirasu et al., 1997; Delledonne et al., 1998; Klessig et al., 2000; Martinez et al., 2000). EDS1 (Falk et al., 1999; Feys et al., 2001) and PAD4 (Zhou et al., 1998; Jirage et al., 1999) operate upstream of SA accumulation during resistance responses in which they are required. In these contexts, their expression levels are enhanced by the application of $S A$, suggesting that $E D S 1$ and $P A D 4$ are regulated by SA-dependent positive feedback (Falk et al., 1999; Jirage et al., 1999; Feys et al., 2001). We suggest that the flux through this feedback is regulated by LSD1 (Figure 6). Experiments are in progress to determine directly the role of SA and the SA response regulator NPR1/NIM1 (Cao et al., 1997; Ryals et al., 1997) in Isd1-dependent RCD. Notably, 
ndr1 did not significantly suppress lesioning in Isd1 after $\mathrm{BTH}$ treatment. This indicates that, in contrast to EDS1 and $P A D 4, N D R 1$ is not essential for BTH signaling (and presumably $S A$ signaling) in relation to $L S D 1$-regulated plant cell death.

\section{EDS1, PAD4, and NDR1 Mediate ROI-Dependent Signaling}

It was shown previously that RCD in Isd1 plants can be triggered by superoxide furnished by local applications of xanthine and xanthine oxidase (Jabs et al., 1996). Also, superoxide accumulation preceded lesion formation in Isd1 tissue and was detectable in cells bordering the developing lesion by specific NBT staining (Jabs et al., 1996). Thus, LSD1 activity appears to monitor a superoxide-dependent signal. Here, we show that EDS1 and $P A D 4$, and interestingly also NDR1, mediate the ROI-derived signal leading to Isd1 RCD. The most compelling evidence for this is the failure of the eds $1 / / s d 1$, pad4/lsd1, and ndr1/lsd1c plants to initiate spreading lesions after local provision of superoxide, supplied either by RB (Table 1) or xanthine/xanthine oxidase applications. These data imply that all three disease resistance regulators express this particular function in unchallenged cells.

The activities of EDS1 and PAD4 in ROI signaling leading to RCD, therefore, are genetically distinct from their roles during the oxidative burst associated with a pathogeninduced HR (Figure 6). This finding strengthens the notion that EDS1 and PAD4 have a second function operating downstream or independently of the HR. We postulate that this second function helps establish the signal normally required to initiate Isd1 RCD. However, three observations suggest a different role for NDR1 in ROI signaling. (1) ndr1 attenuated the oxidative burst during the HR through RPS4 or RPP4, whereas it enhanced the oxidative burst during the HR through RPM1 pathogen recognition. (2) In all of these plantpathogen combinations, ndr1 diminished Isd1 RCD. (3) NDR1 is not required for Isd1 lesions in response to BTH but is required for lesion development in response to ROI provision. These three points lead us to conclude that NDR1 is important in regulating the local ROI status (Figure 6). Imbalances in this system are likely to affect the efficiency of the $\mathrm{HR}$ and consequent local signaling and probably drive RCD in Isd1. Recent studies reveal that the balance of ROI, most particularly $\mathrm{O}_{2}^{-} \cdot \mathrm{H}_{2} \mathrm{O}_{2}$, and $\mathrm{NO}$, is crucial for the establishment of the HR (Delledonne et al., 1998, 2001; Klessig et al., 2000).

We propose that EDS1 and PAD4 are regulators of ROIand SA-dependent signaling in a plant defense potentiation circuit. We suggest that NDR1 is required more proximally for the control of ROI generation and the transduction of a ROI-derived signal at the initial interaction site. In this respect, it is interesting that EDS1 and PAD4, but not NDR1, are components of a basal resistance pathway that limits the growth of virulent pathogens in the absence of plant cell

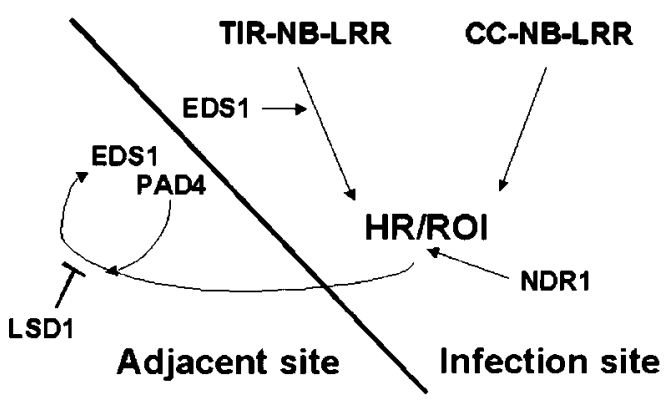

Figure 6. A Model Positioning EDS1, PAD4, and NDR1 in Relation to LSD1 in Plant Defenses.

As shown in the model, RCD in Isd1 mutants is initiated in tissues adjacent to pathogen infection foci. The roles of EDS1, PAD4, and NDR1 in Isd1 RCD are separable from events controlling the plant $\mathrm{HR}$ and its accompanying oxidative burst (ROI) that are elicited upon avirulent pathogen recognition. EDS1, but not PAD4, functions upstream of localized $\mathrm{HR}$ and $\mathrm{ROI}$ production in resistance conditioned by TIR-NB-LRR-type $R$ genes. In contrast, resistance conditioned by CC-NB-LRR-type $R$ genes operates independently of EDS1 or PAD4 but requires NDR1. Irrespective of the different requirements for EDS1 and PAD4 at initial infection foci, both components are essential for signal relay leading to RCD in Isd1. Because EDS1 and PAD4 are also necessary for Isd1 RCD in response to the artificial provision of ROI or an active SA analog, we propose that EDS1 and PAD4 regulate a ROI/SA-dependent defense signal amplification loop. Flux through this loop is modulated by LSD1. NDR1 also is required for maximal lesion development in Isd1 plants in response to pathogens. The data suggest that NDR1 acts more proximally by regulating $\mathrm{ROI}$ balance and transduction of ROI-dependent signals at infection sites (see Discussion for more details).

death (Glazebrook et al., 1996; Parker et al., 1996; Reuber et al., 1998). It is conceivable that basal resistance is a reflection of the EDS1 and $P A D 4$ resistance-potentiating activities demonstrated here. Recent analyses revealed a requirement for EDS1 and PAD4 in constitutive SA-dependent resistance pathways induced by the cpr1 and cpr6 mutations (Clarke et al., 2001; Jirage et al., 2001) that is also consistent with resistance-potentiating roles.

\section{ROI Requirements Differ between the HR and LSD1-Controlled Plant Cell Death}

Our analysis of ROI accumulation suggests that the nature of ROls produced by cells undergoing the HR is different from that of ROls associated with signaling from those cells, and monitored by $L S D 1$. We detected superoxide, but not $\mathrm{H}_{2} \mathrm{O}_{2}$, in living cells bordering spreading Isd1 lesions, as shown previously (Jabs et al., 1996). Our failure to observe $\mathrm{H}_{2} \mathrm{O}_{2}$ at these margins was surprising, because superoxide would be expected to dismutate to $\mathrm{H}_{2} \mathrm{O}_{2}$. LSD1 is required for the SA-dependent induction of antioxidant copper-zinc 
superoxide dismutase (Cu-Zn SOD) (Kliebenstein et al., 1999) and potentially other antioxidant genes. Thus, a simple explanation is that there is no, or there is delayed, accumulation of Cu-Zn SOD in Isd1 and hence no dismutation. This simple model is weakened by the unlikelihood that $\mathrm{Cu}$ $\mathrm{Zn}$ SOD operates in the apoplast, where $\mathrm{O}_{2}{ }^{-} \cdot$ is first produced during the oxidative burst (Bolwell, 1999).

Another possibility is that superoxide produced by cells at $\mathrm{HR}$ margins, where LSD1 is proposed to function, is converted to something other than $\mathrm{H}_{2} \mathrm{O}_{2}$. This could reflect an interplay between $\mathrm{O}_{2}^{-} \cdot$ with other $\mathrm{ROI}$ molecules, $\mathrm{SA}$, or antioxidant systems. In animal cells, superoxide can react with $\mathrm{NO}$ to produce peroxynitrite $\left(\mathrm{ONOO}^{-}\right)$, a highly reactive redox species that serves as a signal or as a cytotoxic agent, depending on its level and the availability of other redox molecules (Bonfoco et al., 1995; Lin et al., 1995). Delledonne et al. (2001) propose that $\mathrm{O}_{2}{ }^{-} \cdot$ production and its dismutation to $\mathrm{H}_{2} \mathrm{O}_{2}$ regulate a balance of $\mathrm{H}_{2} \mathrm{O}_{2} / \mathrm{NO}$ that, when disturbed, leads to HR. They argue against a direct role in cell killing for $\mathrm{ONOO}^{-}$. An alternate explanation is that the $\mathrm{H}_{2} \mathrm{O}_{2}$ produced is locally unavailable for polymerization with $\mathrm{DAB}$. This could be caused by changes in the cellular $\mathrm{pH}$ specific to these mutant backgrounds (DAB staining is effective only at $\mathrm{pH}$ values between 5.5 and 6.0; Thordal-Christensen et al., 1997) or by a surge of ROI scavenging enzymes (Vanacker et al., 2000). Cells are permeable to DAB and $\mathrm{H}_{2} \mathrm{O}_{2}$ (Thordal-Christensen et al., 1997), ruling out the possibility that $\mathrm{H}_{2} \mathrm{O}_{2}$ generated within the cell would be inaccessible for detection. Our data clearly suggest that the fate of superoxide produced in cells undergoing an HR is different from that generated locally during Isd 1 lesion development. This implies that signaling extending from infected cells is controlled differently than it is in the infected cells themselves.

Conversely, we observed $\mathrm{H}_{2} \mathrm{O}_{2}$, but not superoxide, at infection foci. Superoxide is an unstable redox molecule that rapidly dismutates enzymatically or nonenzymatically to $\mathrm{H}_{2} \mathrm{O}_{2}$ (Lamb and Dixon, 1997). Overwhelming evidence suggests that production of superoxide at the cell surface is the proximal event in the plant oxidative burst (Bolwell, 1999). However, other extracellular and intracellular mechanisms may contribute to ROI generation during the oxidative burst (Allan and Fluhr, 1997; Martinez et al., 1998; Bolwell, 1999). The transience of the oxidative burst and the inherent instability of superoxide may account for our failure to observe NBT-reactive material at infection sites or in cells supplied with superoxide by exogenous RB application. RB was applied onto the leaf surface and therefore would release superoxide into the plant apoplast that would be accessible to NBT (Baker and Orlandi, 1995).

\section{Putative Signaling Functions of EDS1, PAD4, and LSD1}

Our results draw an important genetic link between the disease resistance-promoting functions of EDS1, PAD4, and
NDR1 and the negative regulation of plant cell death exerted by LSD1 (Figure 6), raising questions about the biochemical roles of these proteins in healthy and pathogen-challenged plants. $L S D 1$ encodes a zinc finger protein with similarity to the GATA-type family of transcription factors. EDS1 and PAD4 share homology with the catalytic domains of eukaryotic lipases (Falk et al., 1999; Jirage et al., 1999), although hydrolytic activities have not been demonstrated. It is possible, therefore, that they process ROl-activated signal intermediates spreading from infected to surrounding noninfected cells to perpetuate plant defense responses. In animals (Serhan et al., 1996; Stafforini et al., 1997) and plants (Farmer et al., 1998; Sanz et al., 1998; Rustérucci et al., 1999), activated fatty acids are important signaling molecules produced in response to certain pathogens and after wounding. Thus, EDS1 and PAD4 may potentiate resistance by processing ROI- and SA-activated molecules. The production of such molecules, whether lipid based or otherwise, would normally lead to cell death only if their levels passed a cell death control threshold. Obviously, in an Isd1 null mutant, these levels need not be high to initiate RCD. The biochemical role of NDR1 also remains to be resolved, although its potential membrane association (Century et al., 1997) may be important in regulating cellular communication between external and internal redox systems. Elucidating the activities, cellular localization, and molecular associations of all of these signaling components should provide important insights into their precise functions in plant disease resistance.

\section{METHODS}

\section{Plant Material and Cultivation}

The origins of eds1-1 (Parker et al., 1996) and Isd1 (Dietrich et al., 1997 ) in accession Wassilewskija (Ws-0) have been described previously. The pad4-5 T-DNA insertion mutant also was isolated in Ws-0 (Feys et al., 2001). The T-DNA is inserted 35 bp $5^{\prime}$ to the end of the single intron in the PAD4 gene. The ndr1-1 mutant line in accession Columbia (Col-0) (Century et al., 1997) was kindly provided by Dr. Brian Staskawicz (University of California, Berkeley). Seed were sown on low nutrient compost and grown in a chamber under a light period of $8 \mathrm{hr}\left(\sim 160 \mu \mathrm{E} \cdot \mathrm{m}^{-2} \cdot \mathrm{sec}^{-1}\right)$ at $22^{\circ} \mathrm{C}$ and $65 \%$ relative humidity $(\mathrm{RH})$.

F2 plants derived from selfed F1 plants were genotyped for the Isd1 mutation by polymerase chain reaction (PCR) using a triple primer set (5'-ACCTAACAAAAAGAAAAGTGTGTGAGG-3', 5'-ATAATAAACCCTACTAGCTCTAACAAG-3', and 5'-CTGCTACTTTCATCCAAAC- $\left.3^{\prime}\right)$. The wild-type $L S D 1$ allele produces a 940-bp product, whereas $I s d 1$ gives a 600 -bp product. The Col-0 allele of Isd1 (Isd1c) was constructed by introgressing the Ws-0 allele into a Col-0 line over seven generations and selecting for the mutant allele using the Isd 1 PCR described above. The ndr1/Isd1c double mutant was constructed by crossing $n d r 1-1$ plants with $/ s d 1 \mathrm{c}$, selfing the $\mathrm{F} 1$ plants, and genotyping the segregating F2 plants for the Isd1 mutation (described above) and the ndr1-1 mutation by using the primer set 5'-GGGACGGTTTCAATTCTGTGATAG-3' and 5'-CGAGATTGC- 
TCATTGCCATTGG-3'. The eds1-1 mutation was detected in eds1-1 $\times$ Isd1 F2 plants using the primer set 5'-GGATAGAAGATGAATACAAGCC-3' and 5'-ACCTAAGGTTCAGGTATCTGT-3'. PCR products were digested for at least $4 \mathrm{hr}$ with Mse1, and products were resolved on a $2 \%$ agarose gel. Cleavage of wild-type EDS1 produces three visible bands of 280,180 , and $150 \mathrm{bp}$, whereas eds $1-1$ gives visible products of 240,180 , and $150 \mathrm{bp}$. PCR-based selection of the pad4-5 mutant allele in pad4-5 $\times$ Isd1 F2 plants was as described (Feys et al., 2001). In the initial characterizations of mutant phenotypes, we examined several independent mutant lines. All behaved similarly; hence, more detailed analyses were performed with one representative single and double mutant per genotype.

\section{Pathogen Isolates and Growth Determinations}

Peronospora parasitica $(P p)$ isolates Noco2, Emoy2, and Emwa1 were maintained on the genetically susceptible Arabidopsis accessions Col-0, Oystese, and Ws-0, respectively, as described previously (Dangl et al., 1992). To determine disease symptom development, $P p$ conidiospores were suspended in water $\left(4 \times 10^{4}\right.$ spores $\left./ \mathrm{mL}\right)$ and sprayed onto 10-day-old (for cotyledon assays) or 4-week-old (for leaf assays) plants. Inoculated plants were kept under a sealed propagator lid to achieve high $\mathrm{RH}$ in a growth chamber at $19^{\circ} \mathrm{C}$ under an 8-hr light period (100 to $160 \mu \mathrm{E} \cdot \mathrm{m}^{-2} \cdot \mathrm{sec}^{-1}$ ). Alternatively, a $10-\mu \mathrm{L}$ droplet of $P p$ conidiospores was placed on the leaf surface, and plants were incubated for up to 7 days under the same conditions as used for $P p$ growth assays.

Bacterial pathogen induction of runaway cell death (RCD) was measured by infiltrating suspensions ( $10^{5}$ colony-forming units $/ \mathrm{mL}$ ) of Pseudomonas syringae pv tomato DC3000 expressing either avrRps4 or avrRpm1 into one side of the leaf using a $1.5-\mathrm{mL}$ needleless syringe. Plants were inspected for disease symptoms and/or spreading lesion formation over 6 days under the same conditions as described for the growth assays. Hypersensitive response (HR) tests were performed using $5 \times 10^{7}$ colony-forming units $/ \mathrm{mL}$. Growth of $P$. syringae pv tomato DC3000 expressing avrRps 4 or avrRpm 1 in the various lines was determined by dip inoculation and subsequent growth analysis essentially as described (Innes et al., 1993) with modifications (P. Tornero and J.L. Dangl, unpublished data). Briefly, pots containing 2-week-old plants were immersed for 10 to $15 \mathrm{sec}$ in a suspension containing 2.5 $\times 10^{7}$ colony-forming units $/ \mathrm{mL}\left(\mathrm{OD}_{600}=0.05\right)$ and Silwet $(200 \mu \mathrm{L} / \mathrm{L})$. Plants were kept under high humidity for $1 \mathrm{hr}$, after which time measurement zero was taken. At time 0 and 3 days, bacteria were extracted from the plant tissue and grown on selective agar plates to determine concentration.

\section{Benzothiodiazole Induction of Isd1 RCD}

For chemical induction of RCD, leaves of 4-week-old plants were sprayed with $0.35 \mathrm{mM}$ benzothiodiazole $(\mathrm{BTH})$, which was provided as a gift from Syngenta (Research Triangle Park, NC). Plants were maintained under normal growth conditions and inspected for lesion development over 6 days.

\section{Histochemical Analysis of Plant Cell Death and Pp Development}

Plant cell necrosis induced by pathogen inoculation or chemical treatment, as well as the development of $P p$ mycelium inside cotyledon or leaf tissues, was monitored by staining with lactophenol-try- pan blue and destaining in saturated chloral hydrate as described (Koch and Slusarenko, 1990). Material was mounted on a slide in $60 \%$ glycerol and examined using a light microscope (Axiophot; Zeiss, Jena, Germany). Excised leaves were manipulated in parallel with those used for detection of hydrogen peroxide $\left(\mathrm{H}_{2} \mathrm{O}_{2}\right)$ and maintained under the same conditions (see below).

\section{Histochemical Detection of $\mathrm{H}_{2} \mathrm{O}_{2}$ at Interaction Sites}

Detection of $\mathrm{H}_{2} \mathrm{O}_{2}$ was by endogenous peroxidase-dependent in situ histochemical staining using 3,3-diaminobenzidine (DAB) in a protocol modified from Thordal-Christensen et al. (1997). Leaves of 4-weekold plants were inoculated with a $10-\mu \mathrm{L}$ droplet of $P p$ conidiospores placed on the leaf surface. Leaves were then excised and supplied through the cut petiole with a solution of $1 \mathrm{mg} / \mathrm{mL}$ DAB for $8 \mathrm{hr}$ in light $\left(100\right.$ to $\left.160 \mu \mathrm{E} \cdot \mathrm{m}^{-2} \cdot \mathrm{sec}^{-1}\right)$ or in darkness under the same conditions used to determine $P p$ growth. Subsequently, the DAB solution was replaced with water, and leaves were maintained under the same conditions as before. For assessment of $\mathrm{H}_{2} \mathrm{O}_{2}$ accumulation at $P$. syringae infection sites, excised leaves were allowed to take up DAB solution for $8 \mathrm{hr}$ and then were dipped in bacterial suspensions and incubated as described for the bacterial growth assays except that leaves were kept in the dark. At different times after pathogen inoculation, leaves were cleared for $5 \mathrm{~min}$ in boiling acetic acid/glycerol/ethanol (1:1:3 [v/v/v]) solution. Material was mounted on a slide in $60 \%$ glycerol and examined using a light microscope (Axiophot; Zeiss). $\mathrm{H}_{2} \mathrm{O}_{2}$ was detectable as reddish brown coloration.

\section{Chemical Provision of ROI in Leaves}

Rose bengal (4,5,6,7-tetrachloro-2' $4^{\prime}, 5^{\prime}, 7^{\prime}$-tetraiodofluorescein [RB]; Sigma) is an efficient singlet molecular oxygen $\left({ }^{1} \mathrm{O}_{2}\right)$ producer in aqueous solution (Knox and Dodge, 1984). ${ }^{1} \mathrm{O}_{2}$ gives rise to radical anion superoxide $\left(\mathrm{O}_{2}^{-} \cdot\right)$ and subsequently to $\mathrm{H}_{2} \mathrm{O}_{2}$. RB was applied as a droplet of $10 \mu \mathrm{L}$ (20 mM solution) onto the surface of excised leaves of 4 -week-old plants. These were placed in a growth chamber in the light (160 to $\left.200 \mu \mathrm{E} \cdot \mathrm{m}^{-2} \cdot \mathrm{sec}^{-1}\right)$ for at least $3 \mathrm{hr}$ after RB treatment and maintained for several days under an 8-hr photoperiod at $19^{\circ} \mathrm{C}$ and $65 \% \mathrm{RH}$. Xanthine and xanthine oxidase coinfiltration in leaves of 4- or 5-week-old plants was used to generate superoxide, as described previously (Jabs et al., 1996). Infiltrated plants were maintained under normal plant growth conditions.

\section{ACKNOWLEDGMENTS}

We thank Jeff Chang for critical comments on the manuscript. Research at the Sainsbury Laboratory is funded by the Gatsby Charitable Foundation. C.R. is a recipient of a Marie Curie postdoctoral research training fellowship from the European Commission. Work at the University of North Carolina, Chapel Hill, was supported by National Institutes of Health Grant 5RO1-GM057171-01 to J.L.D. and by support through the University of North Carolina Curriculum in Genetics National Institutes of Health Training Grant T32 GM07092-26 to D.H.A.

Received March 2, 2001; accepted July 5, 2001. 


\section{REFERENCES}

Aarts, N., Metz, M., Holub, E., Staskawicz, B.J., Daniels, M.J., and Parker, J.E. (1998). Different requirements for EDS1 and NDR1 by disease resistance genes define at least two $R$ genemediated signaling pathways in Arabidopsis. Proc. Natl. Acad. Sci. USA 95, 10306-10311.

Allan, A.C., and Fluhr, R. (1997). Two distinct sources of elicited reactive oxygen species in tobacco epidermal cells. Plant Cell 9, 1559-1572.

Baker, C.J., and Orlandi, E.W. (1995). Active oxygen in plant pathogenesis. Annu. Rev. Phytopathol. 33, 299-321.

Bestwick, C.S., Brown, I.R., Bennett, M.H.R., and Mansfield, J.W. (1997). Localization of hydrogen peroxide accumulation during the hypersensitive reaction of lettuce cells to Pseudomonas syringae pv phaseolicola. Plant Cell 9, 209-221.

Bolwell, G.P. (1999). Role of active oxygen species and NO in plant defense responses. Curr. Opin. Plant Biol. 2, 287-294.

Bonfoco, E., Krainc, D., Ankarcrona, M., Nicotera, P., and Lipton, S.A. (1995). Apoptosis and necrosis: Two distinct events induced, respectively, by mild and intense insults with $N$-methyl-D-aspartate or nitric oxide/superoxide in cortical cell cultures. Proc. Natl. Acad. Sci. USA 92, 7162-7166.

Büschges, R., et al. (1997). The barley Mlo gene: A novel control element of plant pathogen resistance. Cell 88, 695-705.

Cao, H., Bowling, S.A., Gordon, S., and Dong, X. (1994). Characterization of an Arabidopsis mutant that is nonresponsive to inducers of systemic acquired resistance. Plant Cell 6, 15831592.

Cao, H., Glazebrook, J., Clarke, J.D., Volko, S., and Dong, X. (1997). The Arabidopsis NPR1 gene that controls systemic acquired resistance encodes a novel protein containing ankyrin repeats. Cell 88, 57-63.

Century, K.S., Holub, E.B., and Staskawicz, B.J. (1995). NDR1, a locus of Arabidopsis thaliana that is required for disease resistance to both a bacterial and a fungal pathogen. Proc. Natl. Acad. Sci. USA 92, 6597-6601.

Century, K.S., Shapiro, A.D., Repetti, P.P., Dahlbeck, D., Holub, E., and Staskawicz, B.J. (1997). NDR1, a pathogen-induced component required for Arabidopsis disease resistance. Science 278, 1963-1965.

Clarke, J.D., Aarts, N., Feys, B.J., Dong, X., and Parker, J.E. (2001). Constitutive disease resistance requires EDS1 in the Arabidopsis mutants cpr1 and cpr6 and is partially EDS1-dependent in cpr5. Plant J. 26, 409-420.

Dangl, J.L., Holub, E.B., Debener, T., Lehnackers, H., Ritter, C., and Crute, I.R. (1992).Genetic definition of loci involved in Arabidopsis-pathogen interactions. In Methods in Arabidopsis Research, C. Koncz, N.H. Chua, and J. Schell, eds (Singapore: World Scientific Publishers), pp. 393-418.

Dangl, J.L., Dietrich, R.A., and Richberg, M.H. (1996). Death don't have no mercy: Cell death programs in plant-microbe interactions. Plant Cell 8, 1793-1807.

Delaney, T.P., Uknes, S., Vernooij, B., Friedrich, L., Weymann, K., Negrotto, D., Gaffney, T., Gut-Rella, M., Kessmann, H., Ward, E., and Ryals, J. (1994). A central role of salicylic acid in plant disease resistance. Science 266, 1247-1250.
Delaney, T.P., Friedrich, L., and Ryals, J.A. (1995). Arabidopsis signal transduction mutant defective in chemically and biologically induced disease resistance. Proc. Natl. Acad. Sci. USA 92, 6602-6606.

Delledonne, M., Xia, Y.J., Dixon, R.A., and Lamb, C. (1998). Nitric oxide functions as a signal in plant disease resistance. Nature 394, 585-588.

Delledonne, M., Zeier, J., Marocco, A., and Lamb, C. (2001). Signal interactions between nitric oxide and reactive oxygen intermediates in the plant hypersensitive disease resistance response. Proc. Natl. Acad. Sci. USA, in press.

Dietrich, R.A., Delaney, T.P., Uknes, S.J., Ward, E.R., Ryals, J.A., and Dangl, J.L. (1994). Arabidopsis mutants simulating disease resistance response. Cell 77, 565-577.

Dietrich, R.A., Richberg, M.H., Schmidt, R., Dean, C., and Dangl, J.L. (1997). A novel zinc finger protein is encoded by the Arabidopsis $L S D 1$ gene and functions as a negative regulator of plant cell death. Cell 88, 685-694.

Durner, J., Wendehenne, D., and Klessig, D.F. (1998). Defense gene induction in tobacco by nitric oxide, cyclic GMP, and cyclic ADP-ribose. Proc. Natl. Acad. Sci. USA 95, 10328-10333.

Falk, A., Feys, B.J., Frost, L.N., Jones, J.D.G., Daniels, M.J., and Parker, J.E. (1999). EDS1, an essential component of $R$ genemediated disease resistance in Arabidopsis, has homology to eukaryotic lipases. Proc. Natl. Acad. Sci. USA 96, 3292-3297.

Farmer, E.E., Weber, H., and Vollenweider, S. (1998). Fatty acid signaling in Arabidopsis. Planta 206, 167-174.

Feys, B.J., and Parker, J.E. (2000). Interplay of signaling pathways in plant disease resistance. Trends Genet. 16, 449-455.

Feys, B.J., Moisan, L.J., Newman, M.A., and Parker, J.E. (2001) Direct interaction between the Arabidosis disease resistance signaling proteins, EDS1 and PAD4. EMBO J. 20, 5400-5411.

Gaffney, T., Friedrich, L., Vernooij, B., Negrotto, D., Nye, G., Uknes, S., Ward, E., Kessmann, H., and Ryals, J. (1993). Requirement of salicylic acid for the induction of systemic acquired resistance. Science 261, 754-756.

Glazebrook, J. (1999). Genes controlling expression of defense responses in Arabidopsis. Curr. Opin. Plant Biol. 2, 280-286.

Glazebrook, J., Rogers, E.E., and Ausubel, F.M. (1996). Isolation of Arabidopsis mutants with enhanced disease susceptibility by direct screening. Genetics 143, 973-982.

Glazebrook, J., Zook, M., Mert, F., Kagan, I., Rogers, E.E., Crute, I.R., Holub, E.B., Hammerschmidt, R., and Ausubel, F.M. (1997). Phytoalexin-deficient mutants of Arabidopsis reveal that $P A D 4$ encodes a regulatory factor and that four $P A D$ genes contribute to downy mildew resistance. Genetics 146, 381-392.

Görlach, J., Volrath, S., Knauf-Beiter, G., Hengy, G., Beckhove, U., Kogel, K.-H., Oostendorp, M., Staub, T., Ward, E., Kessmann, H., and Ryals, J. (1996). Benzothiadiazole, a novel class of inducers of systemic acquired resistance, activates gene expression and disease resistance in wheat. Plant Cell 8, 629-643.

Grant, J.J., and Loake, G.J. (2000). Role of reactive oxygen intermediates and cognate redox signaling in disease resistance. Plant Physiol. 124, 21-29.

Grant, M.R., Godiard, L., Straube, E., Ashfield, T., Lewald, J., Sattler, A., Innes, R.W., and Dangl, J.L. (1995). Structure of the 
Arabidopsis RPM1 gene enabling dual specificity disease resistance. Science. 269, 843-846.

Gray, J., Close, P.S., Briggs, S.P., and Johal, G.S. (1997). A novel suppressor of cell death in plants encoded by the L/s1 gene of maize. Cell 89, 25-31.

Holub, E.B., Beynon, J.L., and Crute, I.R. (1994). Phenotypic and genotypic characterization of interactions between isolates of Peronospora parasitica and accessions of Arabidopsis thaliana. Mol. Plant-Microbe Interact. 7, 223-239.

Innes, R.W., Bisgrove, S.R., Smith, N.M., Bent, A.F., Staskawicz, B.J., and Liu, Y.-C. (1993). Identification of a disease resistance locus in Arabidopsis that is functionally homologous to the RPG1 locus of soybean. Plant J. 4, 813-820.

Jabs, T., Dietrich, R.A., and Dangl, J.L. (1996). Initiation of runaway cell death in an Arabidopsis mutant by extracellular superoxide. Science 273, 1853-1856.

Jirage, D., Tootle, T.L., Reuber, T.L., Frost, L.N., Feys, B.J., Parker, J.E., Ausubel, F.M., and Glazebrook, J. (1999). Arabidopsis thaliana PAD4 encodes a lipase-like gene that is important for salicylic acid signaling. Proc. Natl. Acad. Sci. USA 96, 13583-13588.

Jirage, D., Zhou, N., Cooper, B., Clarke, J.D., Dong, X., and Glazebrook, J. (2001). Constitutive salicylic acid-dependent signaling in cpr1 and cpr6 mutant requires PAD4. Plant J. 26, 395-407.

Jones, D.A. (2000). Resistance genes and resistance protein functions. In Molecular Plant Pathology, Vol. 4, M. Dickinson and J. Beynon, eds (Sheffield, UK: Academic Press), pp. 108-143.

Klessig, D.F., et al. (2000). Nitric oxide and salicylic acid signaling in plant defense. Proc. Natl. Acad. Sci. USA 97, 8849-8855.

Kliebenstein, D.J., Dietrich, R.A., Martin, A.C., Last, R.L., and Dangl, J.L. (1999). LSD1 regulates salicylic acid induction of copper zinc superoxide dismutase in Arabidopsis thaliana. Mol. PlantMicrobe Interact. 12, 1022-1026.

Knox, J.P., and Dodge, A.D. (1984). Photodynamic damage to plant tissue by rose bengal. Plant Sci. Lett. 37, 3-7.

Koch, E., and Slusarenko, A. (1990). Arabidopsis is susceptible to infection by a downy mildew fungus. Plant Cell 2, 437-445.

Lamb, C., and Dixon, R.A. (1997). The oxidative burst in plant disease resistance. Annu. Rev. Plant Physiol. Plant Mol. Biol. 48, 251-275.

Lin, K.-T., Xue, J.-Y., Nomen, M., Spur, B., and Wong, P.Y.-K. (1995). Peroxynitrite-induced apoptosis in HL-60 cells. J. Biol. Chem. 270, 16487-16490.

Martinez, C., Montillet, J.L., Bresson, E., Agnel, J.-P., Dai, G.H., Daniel, J.F., Geiger, J.P., and Nicole, M. (1998). Apoplastic peroxidase generates superoxide anions in cells of cotton cotyledons undergoing the hypersensitive reaction to Xanthomonas campestris pv. malvacearum race 18. Mol. Plant-Microbe Interact. 11, 1038-1047.

Martinez, C., Baccou, J.-C., Bresson, E., Baissac, Y., Daniel, J.-F., Jalloul, A., Montillet, J.-L., Geiger, J.-P., Assigbetsé, K., and Nicole, M. (2000). Salicylic acid mediated by the oxidative burst is a key molecule in local and systemic responses of cotton challenged by an avirulent race of Xanthomonas campestris pv malvacearum. Plant Physiol. 122, 757-766.

McDowell, J.M., and Dangl, J.L. (2000). Signal transduction in the plant immune response. Trends Biochem. Sci. 25, 79-82.
McDowell, J.M., Cuzick, A., Can, C., Beynon, J., Dangl, J.L., and Holub, E.B. (2000). Downy mildew (Peronospora parasitica) resistance genes in Arabidopsis vary in functional requirements for NDR1, EDS1, NPR1 and salicylic acid accumulation. Plant J. 22, 523-529.

Morel, J.B., and Dangl, J.L. (1997). The hypersensitive response and the induction of cell death in plants. Cell Death Differ. 4, 671-683.

Mur, L., Bi, Y.-M., Darby, R.M., Firek, S., and Draper, J. (1997). Compromising early salicylic acid accumulation delays the hypersensitive response and increases viral dispersal during lesion establishment in TMV-infected tobacco. Plant J. 12, 1113-1126.

Nawrath, C., and Métraux, J.-P. (1999). Salicylic acid inductiondeficient mutants of Arabidopsis express PR-2 and PR-5 and accumulate high levels of camalexin after pathogen inoculation. Plant Cell 11, 1393-1404.

Parker, J.E., Holub, E.B., Frost, L.N., Falk, A., Gunn, N.D., and Daniels, M.J. (1996). Characterization of eds1, a mutation in Arabidopsis suppressing resistance to Peronospora parasitica specified by several different RPP genes. Plant Cell 8, 2033-2046.

Parker, J.E., Feys, B.J., Van der Biezen, E.A., Noël, N., Aarts, N., Austin, M.J., Botella, M.A., Frost, L.N., Daniels, M.J., and Jones, J.D.G. (2000). Unravelling $R$ gene-mediated disease resistance pathways in Arabidopsis. Mol. Plant Pathol. 1, 17-24.

Reuber, T., Plotnikova, J.M., Dewdney, J., Rogers, E.E., Wood, W., and Ausubel, F.M. (1998). Correlation of defense gene induction defects with powdery mildew susceptibility in Arabidopsis enhanced disease susceptibility mutants. Plant J. 16, 473-485.

Rogers, E.E., and Ausubel, F.M. (1997). Arabidopsis enhanced disease susceptibility mutants exhibit enhanced susceptibility to several bacterial pathogens and alterations in $P R-1$ gene expression. Plant Cell 9, 305-316.

Rustérucci, C., Montillet, J.-L., Agnel, J.-P., Battesti, C., Alonso, B., Knoll, A., Bessoule, J.-J., Etienne, P., Suty, L., Blein, J.-P., and Triantaphylides, C. (1999). Involvement of lipoxygenasedependent production of fatty acid hydroperoxides in the development of the hypersensitive cell death by cryptogein on tobacco leaves. J. Biol. Chem. 274, 36446-36455.

Ryals, J., Weymann, K., Lawton, K., Friedrich, L., Ellis, D., Steiner, H.Y., Johnson, J., Delaney, T.P., Jesse, T., Vos, P., and Uknes, S. (1997). The Arabidopsis NIM1 protein shows homology to the mammalian transcription factor inhibitor $\mathrm{lkB}$. Plant Cell 9, 425-439.

Sanz, A., Moreno, J.I., and Castresana, C. (1998). PIOX, a new pathogen-induced oxygenase with homology to animal cyclooxygenase. Plant Cell 10, 1523-1537.

Schmidt, H.H.W., and Walter, U. (1994). NO at work. Cell 78, 919-925.

Serhan, C.N., Haeggström, J.Z., and Leslie, C.C. (1996). Lipid mediator networks in cell signaling: Update and impact of cytokines. FASEB J. 10, 1147-1158.

Shirasu, K., Nakajima, H., Rajasekhar, V.K., Dixon, R.A., and Lamb, C. (1997). Salicylic acid potentiates an agonist-dependent gain control that amplifies pathogen signals in the activation of defense mechanisms. Plant Cell 9, 261-270.

Stafforini, D.M., McIntyre, T.M., Zimmerman, G.A., and Prescott, 
S.M. (1997). Platelet-activating factor acetylhydrolases. J. Biol. Chem. 272, 17895-17898.

Staskawicz, B.J., Ausubel, F.M., Baker, B.J., Ellis, J.G., and Jones, J.D.G. (1995). Molecular genetics of plant disease resistance. Science 268, 661-667.

Thordal-Christensen, H., Zhang, Z.G., Wei, Y.D., and Collinge, D.B. (1997). Subcellular localization of $\mathrm{H}_{2} \mathrm{O}_{2}$ in plants: $\mathrm{H}_{2} \mathrm{O}_{2}$ accumulation in papillae and hypersensitive response during the barley-powdery mildew interaction. Plant J. 11, 1187-1194.
Vanacker, H., Carver, T.L.W., and Foyer, C.H. (2000). Early $\mathrm{H}_{2} \mathrm{O}_{2}$ accumulation in mesophyll cells leads to induction of glutathione during the hypersensitive response in the barley-powdery mildew interaction. Plant Physiol. 123, 1289-1300.

Yang, Y.O., Shah, J., and Klessig, D.F. (1997). Signal perception and transduction in defense responses. Genes Dev. 11, 1621-1639.

Zhou, N., Tootle, T.L., Tsui, F., Klessig, D.F., and Glazebrook, J. (1998). PAD4 functions upstream from salicylic acid to control defense responses in Arabidopsis. Plant Cell 10, 1021-1030. 
The Disease Resistance Signaling Components EDS1 and PAD4 Are Essential Regulators of the Cell Death Pathway Controlled by $L S D 1$ in Arabidopsis

Christine Rustérucci, Daniel H. Aviv, Ben F. Holt III, Jeffery L. Dangl and Jane E. Parker Plant Cell 2001;13;2211-2224

DOI 10.1105/tpc.010085

This information is current as of July 22, 2020

References

Permissions

eTOCs

CiteTrack Alerts

Subscription Information
This article cites 62 articles, 36 of which can be accessed free at: /content/13/10/2211.full.html\#ref-list-1

https://www.copyright.com/ccc/openurl.do?sid=pd_hw1532298X\&issn=1532298X\&WT.mc_id=pd_hw1532298X

Sign up for eTOCs at:

http://www.plantcell.org/cgi/alerts/ctmain

Sign up for CiteTrack Alerts at:

http://www.plantcell.org/cgi/alerts/ctmain

Subscription Information for The Plant Cell and Plant Physiology is available at: http://www.aspb.org/publications/subscriptions.cfm 